\title{
STUDY MIKROBIOLOGIS KEFIR DENGAN WAKTU SIMPAN BERBEDA
}

\author{
LINDAWATI, S. A., N. L. P. SRIYANI, M. HARTAWAN, DAN I G. SURANJAYA \\ Fakultas Peternakan Universitas Udayana Denpasar-Bali \\ Jl. PB. Soedirman, Denpasar Bali \\ e-mail: srianggrenilindawati@yahoo.co.id
}

\begin{abstract}
ABSTRAK
Penelitian ini bertujuan untuk mengetahui kualitas mikrobiologis kefir dengan waktu simpan sampai 12 hari dengan bakteri asam laktat yang stabil. Penelitian ini menggunakan rancangan acak lengkap (RAL) dengan lima perlakuan dan setiap perlakuan terdiri dari empat ulangan. Kelima perlakuan itu adalah $\mathrm{T}_{\mathrm{o}}$ (kefir dengan waktu simpan o hari), $\mathrm{T}_{3}$ (kefir dengan waktu simpan 3 hari), $\mathrm{T}_{6}$ (kefir dengan waktu simpan 6 hari), $\mathrm{T}_{9}$ (kefir dengan waktu simpan 9 hari), dan $\mathrm{T}_{12}$ (kefir dengan waktu simpan 12 hari). Hasil penelitian menunjukkan bahwa total bakteri asam laktat pada kefir dengan waktu simpan o-12 hari diperoleh $2,81 \cdot 10^{7}-9,65 \cdot 10^{7} \mathrm{cfu} / \mathrm{g}$. Kisaran nilai $\mathrm{pH}$ pada semua perlakuan berkisar antara 3,52-3,88, sedangkan total asam menunjukan bahwa semakin lama waktu simpan kefir semakin meningkat nilai total asamnya $(1,75-5,57 \%)$ serta tidak ditemukan adanya pertumbuhan E.coli sebagai indikator bakteri sanitasi. Dari hasil penelitian dapat disimpulkan bahwa kefir dengan waktu simpan sampai 12 hari pada suhu $5^{\circ} \mathrm{C}$ memiliki kualitas mikrobiologi yang baik dengan bakteri asam laktat berkisar antara 2,81 $10^{7}-5,98 \cdot 10^{7} \mathrm{cfu} / \mathrm{g} ; \mathrm{pH} 3,52-3,88$; total asam 1,75-3,45\%; dan tidak ditemukan adanya pertumbuhan E. coli.
\end{abstract}

Kata kunci: kefir, umur simpan, bakteri asam laktat

THE STUDY OF MICRIBIOLOGICAL KEFIR IN DIFFERENT STORAGE DURATION

\begin{abstract}
This experiment was aimed to determine the quality of microbiological kefir with lactic acid bakteria with 12 days storage at $5^{\circ} \mathrm{C}$ temperature. It was using a completely randomized design (CRD) with five treatments and four replications. The treatments were $\mathrm{T}_{\mathrm{o}}$ (kefir stored in for $\mathrm{o}$ day); $\mathrm{T}_{3}$ (kefir stored for 3 days); $\mathrm{T}_{6}$ (kefir stored for 6 days); $\mathrm{T}_{9}$ (kefir stored for 9 days) and $\mathrm{T}_{12}$ (kefir stored for 12 days).The results showed that the lactic acid bacteria in kefir with shelf life $0-12$ days obtained $2.81 \cdot 10^{7}-9.6 \cdot 10^{7} \mathrm{cfu} / \mathrm{g}$. The range of $\mathrm{pH}$ value of kefir in the whole treatments were 3.52-3.88 while total acid longer shelf life increased with the range of 1.75-5.57\%. This was not also found in the growth of E.coli. Based on the results can be concluded that kefir stored up to 12 days at $5^{\circ} \mathrm{C}$ temperature has quality of microbiology kefir with lactic acid bakteria2,81·10 $-5,98 \cdot 10^{7} \mathrm{cfu} / \mathrm{g}$; $\mathrm{pH} 3.52-3.88$; total acid $1.75-3.45 \%$ and not found in the growth of E.coli as an indicator of sanitation.
\end{abstract}

Keywords: kefir, shelf life, lactic acid bacteria

\section{PENDAHULUAN}

Susu merupakan bahan pangan yang mempunyai kandungan gizi yang tinggi dan media yang baik untuk pertumbuhan mikroba, sehingga susu sangat cepat mengalami kerusakan. Untuk mengantisipasi hal tersebut, maka dilakukan pengolahan. Salah satu produk pengolahan susu tersebut adalah kefir. Kefir merupakan minuman susu yang difermentasi dengan meggunakan biji kefir sebagai starter yang mengandung bakteri asam laktat dan yeast. Produk minuman ini dipercaya memberikan pengaruh positif terhadap kesehatan karena mengandung mikroba yang dapat menghambat pertumbuhan bakteri pathogen Gram positif dan bakteri Gram negatif, dan apabila dikonsumsi dapat menjaga keseimbangan mikroba saluran usus dan merangsang gerak peristaltik saluran cerna (Wood, 1999). Mikroflora biji kefir ini dapat berfungsi sebagai penghambat bakteri pathogen. Yukuchi et al. (1992) menyatakan bahwa bakteri asam laktat yang terdapat dalam kefir dapat menekan kolonisasi bakteri patogen dalam saluran pencernaan, sehingga berpotensi sebagai minuman kesehatan. Menurut Codex persyaratan jumlah sel hidup probiotik dalam susu fermentasi minimal $10^{7} \mathrm{cfu} / \mathrm{g}$ (Anonymous, 2008), karena konsentrasi minimum dari bakteri probiotik yang efektif saat dikonsumsi, bakterinya berkisar $10^{8}$ $10^{9}$ per-ml, hal ini untuk mengantisipasi terjadinya 
pengurangan selama penyimpanan (Nurtekto, 2009). Rarah (1999), mikroflora biji kefir terdiri dari bakteri asam laktat jenis Streptococcus (58,3\%), Lactobacillus (35,4\%), dan khamir (6,3\%) (Rarah, 1999). Aktivitas bakteri asam laktat dari biji kefir pada pembuatan kefir akan mengubah laktosa menjadi asam laktat, sehingga pH kefirmenurun. Kondisi ini menyebabkan bakteri pathogen tidak dapat tumbuh.

Mikroba berada di semua tempat, seperti pada air, tanah, udara, peralatan, dan tangan manusia, sehingga tidak menutup kemungkinan bahwa dalam proses pembuatan kefir secara tradisional terjadi pencemaran oleh bakteri, seperti E. Coli sebagai indikator bakteri sanitasi pada proses pembuatan kefir. Bakteri ini merupakan flora normal dalam saluran pencernaan hewan dan manusia. Kontaminasi bakteri ini pada makanan biasanya berasal dari kontaminasi air yang digunakan (Supardi dan Sukamto, 1999). Jumlah bakteri $E$. coli pada susu fermentasi tidak boleh melebihi $3 \mathrm{koloni} / \mathrm{ml}$.

Waktu simpan merupakan kriteria kualitas produk yang penting dalam ketentuan standar produksi. Kefir biasanya disimpan pada suhu $4^{\circ} \mathrm{C}$ agar kualitasnya dapat dipertahankan. Harald (2002) menyatakan bahwa kefir yang disimpan pada suhu $4^{\circ} \mathrm{C}$ masih berkualitas baik selama 14 hari. Pada umumnya kefir dipasaran memiliki umur yang berbeda, perbedaan umur akan berpengaruh terhadap populasi mikroba dalam kefir. Farnworth dan Mainville (2003) menyatakan bahwa stabilitas dan rasio komposisi mikroorganisme dalam kefir saat produksi sampai waktu konsumsi sangat diperlukan informasi oleh konsumen.

\section{MATERI DAN METODE}

\section{Materi}

Materi yang digunakan dalam penelitian ini, susu sapi segar yang diperoleh dari perusahaan susu sapi di Denpasar dan biji kefir dari Laboratorium Ilmu Ternak Perah, Fakultas Peternakan IPB, Bogor.

\section{Metode}

Penelitian ini menggunakan rancangan acak lengkap (RAL) dengan limaperlakuan dan setiap perlakuan terdiri dari empat ulangan. Adapun kelima perlakuan tersebut: To (kefir waktu simpan o hari); T3 (kefir waktu simpan 3 hari);T6 ( kefir waktu simpan 6 hari); T9 (kefir waktu simpan 9 hari); T12 (kefir waktu simpan 12 hari)

\section{Pembuatan Kefir}

Proses pembuatan kefir mengikuti metode Ot'es dan Cagindi (2003). Susu sapi segar dipasteurisasi pada suhu $85^{\circ} \mathrm{C}$ selama 30 menit dan diturunkan suhunya sampai pada suhu kamar $\pm 27^{\circ} \mathrm{C}$, kemudian diinokulasi dengan biji kefir sebanyak $5 \%$ dan diaduk hingga rata, setelah itu di tuangkan ke dalam gelas toples yang steril dan diinkubasi pada suhu kamar $\left(25 \pm 1^{\circ} \mathrm{C}\right)$ selama 20 jam, sehingga susu mengental menjadi kefir. Kefir ini kemudian disaring untuk memisahkan biji kefir dari substrat kefir. Biji kefir kemudian disimpan untuk digunakan pada inokulasi selanjutnya, sedangkan kefir (substrat aktif) dimasukkan kedalam toples steril dan disimpan pada suhu $5^{\circ} \mathrm{C}$ digunakan untuk perlakuan, dan selanjutnya dilakukan pengujian. Untuk lebih jelasnya dapat dilihat pada Gambar 1.

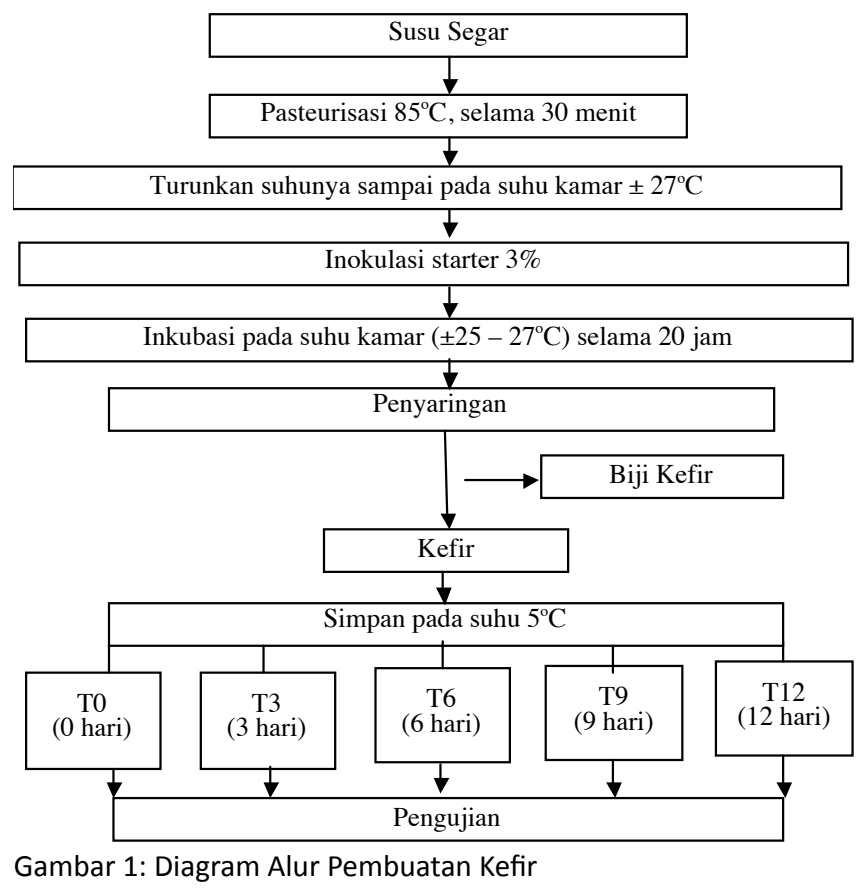

\section{Peubah yang diamati}

Peubah yang diamati, total bakteri, total bakteri asam laktat, Escherichiacoli, pH, dan total asam pada kefir.

\section{Penentuan Total Bakteri, Bakteri Asam Laktat (BAL), E.coli}

Total bakteri adalah jumlah seluruh bakteri yang terdapat dalam kefir. Perhitungan total bakteri dilakukan dengan penanaman metode tuang (Swanson et al., 1985) menggunakan bahan media NA (Nutrient Agar). Sebanyak 10 gram sampel dimasukkan kedalam tabung pengencer yang telah berisi $90 \mathrm{ml}$ bacteriological peptone $0,1 \%$ steril, sehingga diperoleh pengenceran $10^{4}$ dan dikocok hingga homogen. Kemudian dipipet sebanyak $1 \mathrm{ml}$ dari pengenceran $10^{-4}$ dimasukkan ke dalam tabung berisi $9 \mathrm{ml}$ bacteriological peptone $0,1 \%$ steril sehingga diperoleh pengenceran $10^{-2}$. Begitu seterusnya dibuat seri pengenceran sampai $10^{-6}$. Selanjutnya dilakukan penanaman dengan metode 
tuang yang diambil dari tingkat pengenceran $10^{-5}$ dan $10^{-6}$. Dari masing-masing pengenceran tersebut, diambil $1 \mathrm{ml}$ dengan pipet, dimasukan ke dalam cawan petri steril. Selanjutnya dituangkan sebanyak 15-20 ml NA (Nutrient Agar) agar steril yang telah didinginkan sampai $45^{\circ} \mathrm{C}$ dan digoyang perlahan. Setelah media agar padat, selanjutnya diinkubasi pada suhu $30^{\circ} \mathrm{C}$ selama 24-48 jam. Begitu juga untuk penanaman BAL dengan metode yang sama, dan media yang digunakan MRSA. Untuk penanaman E.coli dilakukan dengan metode sebar, diambil dari tingkat pengenceran $10^{-1}$ sebanyak $0.1 \mathrm{ml}$ dimasukan kedalam cawan petri steril yang sudah berisi media 15-20 ml EMBA (Eosine Methylene Blue Agar) steril dalam keadaan padat, kemudian diratakan dengan batang bengkok supaya sampel tersebar merata didalam media. Selanjutnya diinkubasi pada suhu $37^{\circ} \mathrm{C}$ selama 24-48 jam. Koloni yang tumbuh untuk bakteri E. coli berwarna hijau metalik. Metode yang digunakan untuk menghitung jumlah koloni yang tumbuh, metode hitungan cawan dengan memilih koloni yang tumbuh berkisar 25-250 koloni dalam cawan petri (Swanson et al., 1985) dengan formula:

Koloni / gram $=$ jumlah koloni percawanan $X \frac{1}{\text { faktor pengenceran }}$

\section{Uji Derajat Keasaman (pH)}

Pengukuran $\mathrm{pH}$ dilakukan dengan menggunakan $\mathrm{pH}$ meter("Action Model 209 pH/ MV meter") (Sudarmadji et al., 1984).

\section{Uji Total Asam}

Total asam ditentukan dengan cara titrasi (Judkins dan Keener, 1966) dihitung sebagai persentase asam laktat dengan rumus :

$$
T A(\%)=\frac{m l N a O H X N N a O H X B M X P}{m l \text { contoh } X 1000} X 100 \%
$$

Keterangan :

$\mathrm{TA}=$ Total asam

$\mathrm{N}=$ Normalitas

$\mathrm{BM}=\quad$ Berat molekul asam laktat (90)

$\mathrm{P}=$ Pengenceran

\section{Analisis Data}

Data yang diperoleh dianalisis dengan sidik ragam dan apabila diperoleh hasil berbeda nyata $(\mathrm{P}<0.05)$ dilanjutkan dengan uji Duncan (Steel dan Torrie, 1998). Data mikroba yang diperoleh sebelum dianalisa, ditransformasikan terlebih dahulu kedalam $\log \mathrm{x}$.

\section{HASIL DAN PEMBAHASAN}

\section{Total Bakteri}

Total bakteri kefir pada semua perlakuan waktu simpan (To sampai T12) tidak berbeda nyata $(\mathrm{P}>0.05)$. Namun jika dilihat dari data pada Tabel 1 total bakteri tertinggi diperoleh pada waktu simpan 9 hari sebesar $1.21 \times 10^{8} \mathrm{cfu} / \mathrm{g}$ dan terendah pada o hari penyimpanan, yaitu $8.00 \times 10^{7} \mathrm{cfu} / \mathrm{g}$. Hal ini disebabkan populasi bakteri tersebut masih dalam fase adaptasi terhadap lingkungan sekitarnya. Pada perlakuan T3 terjadi peningkatan populasi bakteri, karena didominasi oleh aktivitas bakteri asam laktat yang memfermentasi laktosa susu menjadi asam laktat. Pada perlakuan T6 total bakteri mengalami penurunan. Penurunan ini disebabkan bakteri asam laktat mengalami penurunan aktivitas, karena laktosa sebagai sumber energi mengalami penurunan. Disamping itu, total asam pada waktu simpan 6 hari meningkat (5.57\%), sehingga menekan pertumbuhan bakteri asam laktat. Pada penyimpanan 9 hari, total bakteri mengalami peningkatan, karena adanya aktivitas yeast yang menghasilkan alkohol sehingga menyebabkan keasaman kefir berkurang, (Farnworth dan Mainville, 2003). Kondisi ini menyebabkan bakteri asan laktat dapat tumbuh kembali. Pada perlakuan 12 hari, menurun karena bakteri mengalami persaingan. Untuk lebih jelasnya tentang pola pertumbuhannya dapat dilihat pada Gambar1. Perbedaan total bakteri dipengaruhi juga oleh kemampuan bakteri untuk tumbuh pada kondisi $\mathrm{pH}$ minimum, seperti Lactobacillus bulgaricus ( $\mathrm{pH}$ 3.0), Leuconostoc mesenteroides ( $\mathrm{pH} 4.0$ ), Leuconost dextranicum (pH 4.0) (Rashid et al, 2007), dan Streptococcus lactis (pH 4.3) (Roostita, 2008).

Tabel 1. Total Bakteri, Total Bakteri Asam Laktat, Escherichia coli, pH dan Total AsamKefir dengan Perlakuan Umur Simpan yang Berbeda.

\begin{tabular}{|c|c|c|c|c|c|c|}
\hline \multirow{2}{*}{ Peubah } & \multicolumn{5}{|c|}{ Perlakuan ${ }^{1)}$} & \multirow{2}{*}{$\mathrm{SEM}^{2)}$} \\
\hline & T0 & T3 & T6 & T9 & T12 & \\
\hline Total Bakteri (koloni/ml) & $8,00 \times 10^{7 a}$ & $1,09 \times 10^{8 \mathrm{a}}$ & $9,37 \times 10^{7 \mathrm{a}}$ & $1,21 \times 10^{8 \mathrm{a}}$ & $8,79 \times 10^{7 \mathrm{a}}$ & $0,3184 \times 10^{7}$ \\
\hline Total BAL (koloni/ml) & $2,81 \times 10^{7 \mathrm{a}}$ & $7,41 \times 10^{8 a}$ & $6,64 \times 10^{7 \mathrm{a}}$ & $9,65 \times 10^{7 \mathrm{a}}$ & $5,98 \times 10^{7 \mathrm{a}}$ & $0,2447 \times 10^{7}$ \\
\hline E.coli (koloni/ml) & 0 & 0 & 0 & 0 & 0 & 0 \\
\hline $\mathrm{pH}$ & $3,88^{\mathrm{a}}$ & $3,73^{\mathrm{bc}}$ & $3,73^{\mathrm{c}}$ & $3,78^{\mathrm{b}}$ & $3,52^{\mathrm{d}}$ & 0,0229 \\
\hline Total Asam (\%) & $1,75^{\mathrm{c}}$ & $2,32^{\mathrm{b}}$ & $5,57^{\mathrm{b}}$ & $4,42^{\mathrm{b}}$ & $3,45^{\mathrm{a}}$ & 0,0519 \\
\hline $\begin{array}{l}\text { Keterangan : } \\
\text { 1) T0 = kefir waktu s } \\
\text { T3 = kefir waktu simp } \\
\text { T6 = kefir waktu sim } \\
\text { T9 = kefir waktu sim } \\
\text { T12 = kefir waktu sin } \\
\text { 2) SEM : "Standart Errc } \\
\text { 3) Nilai dengan huruf y } \\
(P<0,05)\end{array}$ & $\begin{array}{l}\text { impan } 0 \mathrm{~h} \\
\text { Jan } 3 \text { hari } \\
\text { pan } 6 \text { hari } \\
\text { pan } 9 \text { hari } \\
\text { npan } 12 \text { ha } \\
\text { or or The T } \\
\text { ang berbec }\end{array}$ & $\begin{array}{l}\text { ri } \\
\text { ri atments } \\
\text { la pada ba }\end{array}$ & $\begin{array}{l}\text { Means" } \\
\text { ris yang s }\end{array}$ & a menu & kkan b & eda nyata \\
\hline
\end{tabular}

Total Bakteri Asam Laktat (BAL)

Hasil analisis menunjukkan bahwa total bakteri asam laktat kefir pada semua perlakuan waktu simpan To sampai T12 tidak berbeda nyata $(\mathrm{P}>0.05)$. Namun 
dilihat dari data pada Tabel 1, total BAL tertinggi diperoleh pada waktu simpan 9 hari $\left(9.65 \times 10^{7} \mathrm{cfu} / \mathrm{g}\right)$ dan terendah pada waktu simpan o hari $\left(2.81 \times 10^{7} \mathrm{cfu} / \mathrm{g}\right)$. Hal ini disebabkan pada awal fermentasi bakteri asam laktat masih dalam fase adaptasi dari pola pertumbuhanya dan pada awal pertumbuhan sel masih mampu melakukan transport aktif pengeluaran proton, sehingga nutrisi masih dapat ditransport, akan tetapi dengan waktu inkubasi berlangsung terus, jumlah pengeluaran proton dan pemasukan proton menjadi tidak seimbang. Pada perlakuan T3 populasi bakteri asam laktat meningkat karena mampu beradaptasi dan memanfaatkan sumber energi dari laktosa yang ada pada kefir. Meningkatnya populasi bakteri asam laktat pada perlakuan $\mathrm{T}_{3}$ menyebabkan $\mathrm{pH}$ kefir turun dan keasaman meningkat, sehingga bakteri asam laktat yang tidak tahan keasaman terlalu tinggi akan mati, sehingga populasi bakteri asam laktat pada perlakuan T6 menurun. Pada saat bersamaan ragi akan mengambil kesempatan menghidrolisis laktosa, sehingga menghasilkan $\mathrm{CO}_{2}$ dan alkohol. Senyawa $\mathrm{OH}^{-}$dari alkohol akan bereaksi dengan senyawa $\mathrm{H}^{+}$ dari asam laktat, sehingga keasaman kefir turun dan $\mathrm{pH}$ meningkat (Farnworth dan Mainville, 2003). Kondisi ini menyebabkan bakteri asam laktat dapat tumbuh kembali. Viljoen (2001) menambahkan bahwa ragi yang mampu memfermentasi laktosa dapat memberikan nutrisi penting bagi pertumbuhan bakteri asam laktat seperti asam amino dan vitamin, sehingga populasi bakteri asam laktat meningkat kembali pada perlakuan T9. Peningkatan populasi bakteri asam laktat ini menyebabkan keasaman kefir meningkat, sehingga bakteri asam laktat yang tidak tahan asam akan mati atau tidak aktif, sehingga pada hari ke 12 (T12), populasi bakteri asam laktat menurun, untuk lebih jelasnya dapat lihat pada Gambar 1.

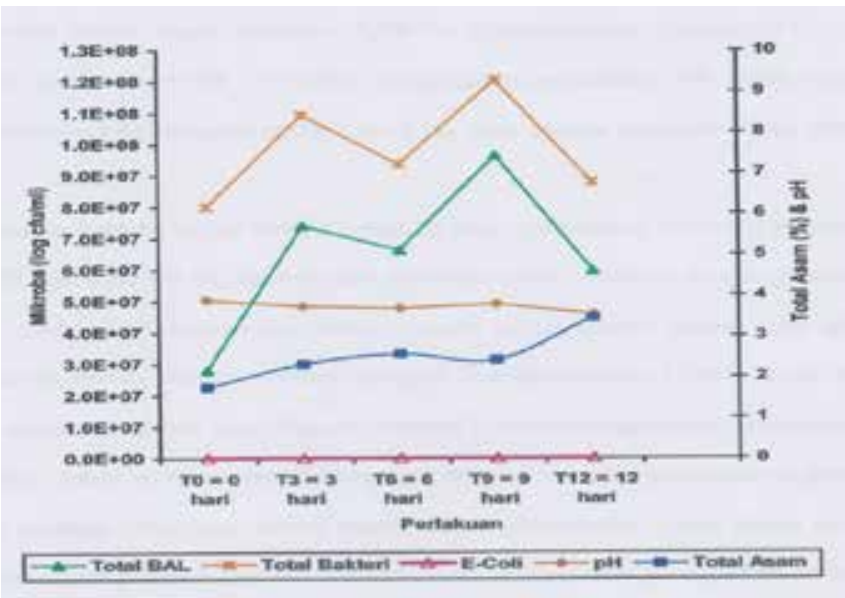

Gambar 1. Grafik Perkembangan Total Bakteri, Total Bakteri Asam Laktat, Escherichiacoli, pH, dan Total Asam Kefir dengan Perlakuan Umur Simpan yang Berbeda

\section{Escherichia coli (E.coli)}

Escherichia coli pada kefir di perlakuan To, T3, T6, T9, dan T12 tidak ditemukan adanya pertumbuhan. Hal ini menunjukkan bahwa kondisi sanitasi yang cukup baik. Supardi dan Sukamto (1999) menyatakan bahwa keberadaan $E$. coli menunjukan kondisi sanitasi yang tidak baik. Terhambatnya pertumbuhan $E$. coli disebabkan oleh kondisi kefir yang bersifat asam. Supardi dan Sukamto (1999) menambahkan bahwa golongan bakteri proteolitik, bakteri Gram negatif berbentuk batang (E. coli) tidak dapat tumbuh pada bahan pangan yang bersifat asam. Selain itu juga ada beberapa spesies bakteri asam laktat yang menyusun biji kefir dapat memproduksi bakteriosin (Wood, 1999).

\section{pH}

Hasil analisis statistik terhadap $\mathrm{pH}$ menunjukkan bahwa nilai $\mathrm{pH}$ kefir pada perlakuan To lebih tinggi ( $\mathrm{P}<0.05)$ sebesar 3,86\%; 5,15\%; 2,58\%; dan 9,28\% dibandingkan dengan perlakuan $\mathrm{T} 3, \mathrm{~T} 6, \mathrm{~T} 9$, dan T12. Perlakuan $\mathrm{T}_{3}$ lebih tinggi $(\mathrm{P}<0,05) \quad 5,63 \%$ dibandingkan dengan T12, serta lebih rendah sebesar 1,32\% dibandingkan dengan perlakuan T9 dan tidak berbeda nyata $(\mathrm{P}>0,05)$, dibandingkan dengan $\mathrm{T} 6$, sedangkan perlakuan T6 lebih tinggi $(\mathrm{P}<0.05)$ sebesar 4,35\% dibandingkan dengan perlakuan T12 serta lebih rendah sebesar 2,64\% dibandingkan dengan T9. Pada perlakuan To $\mathrm{pH}$ kefir lebih tinggi dibandingkan dengan perlakuan $\mathrm{T}_{3}$, hal ini karena selama tiga hari penyimpanan bakteri asam laktat mulai melewati fase adaptasi dan tumbuh memfermentasi laktosa menjadi asam laktat menyebabkan akumulasi asam laktat meningkat sehingga pada hari ke $6 \mathrm{pH}$ kefir turun. Penurunan populasi bakteri asam laktat menyebabkan degradasi laktosa menjadi asam laktat berkurang, sehingga $\mathrm{pH}$ meningkat lagi pada hari ke 9. Selain penurunan populasi bakteri asam laktat, turunnya keasaman juga disebabkan oleh aktivitas ragi mendegradasi laktosa menjadi alkohol, yang menyebabkan $\mathrm{pH}$ naik, dan menyebabkan bakteri asam laktat yang tidak tahan $\mathrm{pH}$ terlalu rendah tumbuh lagi, dan mendegradasi laktosa menjadi asam laktat sehingga pada hari ke $12 \mathrm{pH}$ turun. Hal ini sesuai dengan Viljoen (2001) menyatakan bahwa ragi mampu memfermentasi laktosa memberikan nutrisi penting bagi pertumbuhan bakteri asam laktat seperti asam amino dan vitamin. Fluktuasi nilai $\mathrm{pH}$ kefir selama penyimpanan dapat lihat pada Gambar 1.

\section{Total Asam}

Hasil analisis menunjukkan bahwa nilai total asam kefir pada perlakuan To lebih rendah $(\mathrm{P}<0.05)$ sebesar 24,56\%; 31,90\%; 27,68\%; 49,27\% dibandingkan dengan T3,T6, T9 dan T12. Perlakuan T3 lebih rendah (P>0.05) 
dibandingkan dengan T6 dan T9, serta lebih rendah $(\mathrm{P}<0.05)$ sebesar $32,75 \%$ dibandingkan T12, Perlakuan T6 lebih tinggi $(\mathrm{P}>0.05)$ dibandingkan dengan T9 dan lebih rendah $(\mathrm{P}<0.05)$ sebesar $25,51 \%$ dibandingkan dengan T12, $(\mathrm{P}<0,05)$, sedangkan perlakuan T9 lebih rendah $(\mathrm{P}<0.05)$ sebesar 29,85\% dibandingkan dengan perlakuan T12. Dari Tabel 1 menunjukkan bahwa total asam kefir yang terendah adalah pada perlakuanTo (o hari) sebesar 1,75. Hal ini dipengaruhi oleh populasi bakteri asam laktat masih rendah, sehingga aktivitas bakteri asam laktat untuk memfermentasi laktosa menjadi asam laktat masih rendah. Sedangkan pada kefir perlakuan $\mathrm{T}_{3}$ total asam mulai meningkat, dikarenakan bakteri asam laktat sudah mengalami fase adaptasi. Pada kefir dengan perlakuan T6 total asamnya lebih tinggi dari perlakuan $\mathrm{T}_{3}$, hal ini karena terjadi akumulasi asam laktat sebagai akibat aktifitas bakteri asam laktat yang tinggi, kemudian pada perlakuan T9 total asam menurun kembali dibandingkan dengan perlakuan T6. Hal ini karena aktivitas ragi yang ada dalam kefir yang menghidrolisis laktosa menjadi $\mathrm{CO}_{2}$ dan alkohol sehingga menimbulkan asam, dan oleh karena itu bakteri asam laktat kembali tumbuh. Rahman et al. (1992), peningkatan total asam juga di pengaruhi oleh adanya bakteri-bakteri lain yang memproduksi asam, seperti ragi. Dengan meningkatnya populasi bakteri asam laktat pada perlakuan T9 maka aktifitas bakteri asam laktat untuk memfermentasi laktosa menjadi asam laktat semakin tinggi. Profil total asam untuk lebih jelasnya dapat dilihat pada Gambar 1.

\section{SIMPULAN}

Dari hasil penelitian ini dapat disimpulkan bahwa kefir dengan waktu simpan sampai 12 hari pada suhu $5^{\circ} \mathrm{C}$ masih memiliki kualitas mikrobiologis yang baik dengan bakteri asam laktat 2,81 x lo $7-5,98 \times$ lo $^{7}$ koloni/ $\mathrm{ml}$; $\mathrm{pH} 3,52$ - 3,88; total asam 1,75 - 3,45\%, dan tidak ada pertumbuhan E. coli.

\section{DAFTAR PUSTAKA}

Anonymous. 2008. http://www.codexalimentarius.com/ codex. Stan 243-2003 diakses tanggal 3 Juli 2008

Farnworth, E.R. and I. Mainville. 2003. Kefir: A Fermented Milk Product. In. Famworth E.R. editor. Handbook of Fermented Functional Foods. Food Research and development centre Agriculture and Agri-Food Canada

Harald J. Benson. 2002. Microbiological Applications. New York (Amerika). McGraw-Hill Higher Education

Judkins, H.F. and H.A. Keener. 1966. Milk Production and Processing. John Wiley and Sons, Inc.

Nurtekto. 2009. Ilmu Pangan; Probiotik dan Prebiotik. www. geogle.com. Diakses pada tgl. 13 April 2009.

Ot'es, S and Cagindi, O. 2003. Kefir: A probiotik dairy- composition nutritional and terapeutic aspect. Pakistan J. of Nutrition 2 (2): 54-59

Rahman, A.F, Srikandi, P. R. Wini Ati, Suliantari dan C.C Nurwitri. 1992. Teknologi Fermentasi Susu Departemen Pendidikan Tinggi Pusat antar Universitas Pangandan Gizi . Institut Pertanian Bogor. Bogor.

Rarah. R.A.M. 1999. Isolasi, Identitikasi dan Karakterisasi Mikroflora Biji Kefir serta Substrat Antimikroba Yang Dihasilkan. Laporan Hasil Penelitian. Perpustakaan Pusat IPB. Bogor.

Rashid, Md. H., K. Togo, M. Ueda and T. Miyamoto. 2007. Probiotic Characteristics of Lactic Acid Bacteria Isolated from Traditional Fermented Milk 'Dahi' in Bangladesh. Department of Dairy Science, Bangladesh Agricultural University, Mymensingh-2202, Bangladesh. Graduate School of Natural Science and Technology, Okayama University, 1-1, Naka 1-chome, Tsushima, Okayama 700-8530, Japan. Foods R \& D Center, Kaneka Corporation, Takasago, Hyogo 676-8688, Japan. Pakistan Journal of Nutrition 6 (6): 647-652. ISSN 1680-5194.

Roostita L. B. 2008. Mikrobiologi Pangan. www.geogle.com. Diakses pada Tgl. 25 Juli2008.

Sudarmadji, S.B., Haryono dan Suhardi. 1984. Prosedur Analisa Bahan Pangan dan Pertanian. Edisi Ke-3 Liberty. Yogyakarta.

Supardi, I., dan Sukamto. 1999. Mikrobiologi dalam Pengolahan dan Keamanan Pangan. Penerbit Alumni Bandung.

Swanson, K.M.J., F.F. Busta, E.H. Peterson, and M. Johnson. 1992. Colony Count Methods: In Compendium of Methods for The Microbiological Examination of Foods. $3^{\text {rd }}$ . Edited by C. Vanderzant.,D.F. Splittsoesser. Compiled by the APHA Technical Commite on Microbiological Methods for Foods.

Steel,R.G. and J.H. Torrie. 1998. Principle and Procedure of Statistic. McGraw Hill Book Company Inc. New York.

Viljoen, B.C. 2001. The interaction between yeasts and bacteria in dairy environments. International Journal of Food Microbiology 69: 37-44.

Wood, B.J.B. 1999. Microbiology of Fermented Foods. Second adition. Vol l. Department of Bioscience And Biotechnology University of Strathclyde,Glasgow, UK. Melboume-Madras.

Yukuchi, H., T. Goto., and S. Okonogi. 1992. The Nutritional and Physiological Valueof Fennented Milk and Lactic Milk Drinks. In Function of Fermented Milk. Challengers for Health Science. Y. Nakazawa and A. Hosono (Eds). ElsevierApplied Science. 